\title{
ETHANOL-INDUCED ALTERATIONS IN CARDIAC ENZYMES-AMELIORATIVE EFFECT OF THESPESIA POPULNEA LEAF EXTRACT
}

\author{
SANGEETHA L. A. RAJBANSHI ${ }^{*}$, ARCHANA N. PARANJAPE ${ }^{2}$, VASU APPANNA ${ }^{3}$
}

${ }^{1}$ Babaria Institute of Pharmacy, Varnama, Vadodara, India, ${ }^{2}$ Edutech Learning Solutions Pvt Ltd, Dandiya Bazaar, Vadodara, India, ${ }^{3}$ Faculty of Science and Engineering, Laurentian University, Sudbury, Ontario, Canada

Email: sangeetalr@aol.com

Received: 09 Mar 2017 Revised and Accepted: 30 Jun 2017

\begin{abstract}
Objective: This study covers the estimation of changes in cardiac enzymes such as ATPases and antioxidant enzymes following ethanoladministration in rats, and the possible ameliorative effect of leaf extract of the plant Thespesia populnea (TP) on these changes.

Methods: Male adult Wistar rats were divided into 10 groups of six rats each. Vehicle controls received 5\% gum acacia. Experimental groups received ethanol (20\%, $2 \mathrm{~g} / \mathrm{kg})$; or TP leaf extract (200 mg/kg and $400 \mathrm{mg} / \mathrm{kg}$ respectively); or vitamin E (25 mg/kg); or carvedilol (1 mg/kg) per orally every morning for $6 \mathrm{w}$, individually as well as in combination with ethanol. Following this, changes in the activities of $\mathrm{Na}^{+} \mathrm{ATPase}^{\mathrm{C}} \mathrm{Ca}^{2+} \mathrm{ATPase}$, $\mathrm{Mg}^{2+} \mathrm{ATPase}$, and antioxidant enzymes superoxide dismutase (SOD) and catalase (CAT) were determined in the heart tissue and compared with those in vehicle control.

Results: Ethanol $(20 \%, 2 \mathrm{~g} / \mathrm{kg})$ treatment caused a reduction from the vehicle control in activities of all the examined enzymes, with minimal reduction in $\mathrm{Mg}^{2+}$ ATPase activity (29.26\%) and maximal reduction in CAT activity (71.05\%). With TP leaf extracts of $200 \mathrm{and} 400 \mathrm{mg} / \mathrm{kg}$, vitamin E and carvedilol individually, the vehicle controls showed percent changes in enzyme activities ranging from $-8.24 \%$ for $\mathrm{Mg}^{2+} \mathrm{ATPase}^{2}$ activity to $+109.39 \%$ for $\mathrm{Na}^{+}$ATPase activity caused by carvedilol. When administered along with ethanol, TP leaf extracts, vitamin E and carvedilol reversed the effect of ethanol to various degrees and brought back the enzyme activities to near vehicle control levels. While recovery with $200 \mathrm{mg}$ Thespesia leaf extract was less, ranging from $24.1 \%$ for $\mathrm{Mg}^{2+}$ ATPase activity to $190.91 \%$ for CAT activity, $400 \mathrm{mg}$ Thespesia extract effected a greater recovery, with a minimum of $48.19 \%$ for $\mathrm{Mg}^{2+}$ ATPase activity and a maximum of $222.73 \%$ for CAT activity, as compared with ethanol-treated rats as controls. These effects could be interpreted in terms of the adverse effects of ethanol on cardiac function and the ameliorative effects, primarily the antioxidant potential, of TP leaf extracts, vitamin E and carvedilol.
\end{abstract}

Conclusion: The restoration of enzyme activities with TP leaf extract may promote recovery of cardiac tissue from oxidative damage. Results from the current study indicate that treatment with TP leaf extract reduces ethanol-induced oxidative stress in rat heart and hence may help prevent cardiac damage.

Keywords: Thespesia populnea, Ethanol, Vitamin E, Carvedilol, ATPases, Cardiac toxicity

(C) 2017 The Authors. Published by Innovare Academic Sciences Pvt Ltd. This is an open access article under the CC BY license (http://creativecommons.org/licenses/by/4.0/) DOI: http://dx.doi.org/10.22159/ijpps.2017v9i8.18383

\section{INTRODUCTION}

Widespread alcoholism is a serious problem in the modern society. Chronic excessive ethanol consumption has adverse effects on virtually all organs and tissues in the body [1]. Chronic ethanol ingestion leads to alcoholic cardiac myopathy and impaired cardiac function [2,3]. Ethanol interacts with the cellular constituents, causing profound changes in their structure, organisation and functions. Alteration in lipid components and ion-channels by ethanol can cause changes in membrane function by altering its fluidity [4]. Ethanol consumption has been demonstrated to increase the rate of generation of hydrogen peroxide $\left(\mathrm{H}_{2} \mathrm{O}_{2}\right)$ and hydroxyl radical $(. \mathrm{OH})$ in isolated mitochondria in the presence of metal ion-chelate complexes [5]

Various reports suggest the protective effects of herbs and plants possessing phytochemical principles that could effectively prevent the deleterious effects of ethanol caused primarily due to oxidative damage. The results have been promising [6-8]. In recent years, the importance of antioxidant activities of phytoconstituents has gained attention due to their capacity to act as powerful antioxidants. These constituents presumably can protect the human body from free radicals and reactive oxygen species (ROS) [9]. Phytoactive compounds such as flavonoids, phenolics etc. have been studied mainly for their properties against oxidative damage. Oxidative impairment could lead to various diseases such as cancer, cardiovascular problems, inflammation etc. $[10,11]$.

In the quest to study plants that might provide alleviation from the development of cardiotoxicity, identifying natural products possessing the potential to provide cardioprotection has been one of the most explored areas. Thespesia populnea (TP) of the Malvaceae family is a large tree found in tropical regions and coastal forests of India. The plant is used in the treatment of skin ailments such as scabies, psoriasis, wounds and ulcers [12] and inhibits tumor formation [13]. The leaves, flowers and fruits of TP are used in Ayurveda for the control of diabetes $[14,15]$. Studies on rats showed that its bark and flowers possess astringent, hepatoprotective and antioxidant activities [17, 18]. Phytochemical study of the leaf extract indicates the presence of lupeol, lupenone, $\beta$-sistosterol and, acacetin, kaempferol, quercetin, ferulic acid, vanillic acid, syringic and melilotic acids [19].

Pharmacological and biochemical studies have been carried out on animal tissues to examine the protective effects of TP [14, 16-18]. $\mathrm{Na}^{+} / \mathrm{K}^{+}$ATPase, $\mathrm{Mg}^{2+}$ ATPase and $\mathrm{Ca}^{2+}$ ATPase are integral membrane proteins present in all mammalian cells and are involved in the transport of $\mathrm{Na}^{+}, \mathrm{K}^{+}$, and $\mathrm{Ca}^{2+}$ ions across the plasma membrane. They are necessary for maintaining the electrochemical gradient, which is important in the processes of electrical excitation, contraction of the muscle cells and transport of other ions [20]. It has been demonstrated that ethanol administration alters these enzymes and thus produces organ damage [21, 22]. Superoxide dismutase (SOD) is responsible for the catalytic dismutation of the potentially toxic superoxide anion radical to $\mathrm{H}_{2} \mathrm{O}_{2}$. It is an effective defence of the cells against the endogenous and exogenous generation of ROS [23]. Catalase (CAT) is present in peroxisomes and catalyzes the decomposition of $\mathrm{H}_{2} \mathrm{O}_{2}$ to yield oxygen $\left(\mathrm{O}_{2}\right)$ and 
water $\left(\mathrm{H}_{2} \mathrm{O}\right)$ [24]. The equilibrium between these enzymes is an important process for the effective removal of oxygen stress in intracellular organelles [25].

In view of the importance of ATPase and antioxidant enzymes in biological systems and the possible damage that could be inflicted by ethanol on these enzymes and consequently on heart function, the present study has been taken up to establish the alterations in ATPase and antioxidant enzyme activities due to chronic ethanol administration in rats and to examine the possibility of counteracting ethanol effects by employing TP leaf extract.

\section{MATERIALS AND METHODS}

\section{Procurement and maintenance of experimental animals}

Wistar strain, adult male albino rats $(n=60)$ weighing $200 \pm 20 \mathrm{~g}$ were obtained from Sun Pharma Advanced Research Company Pvt Ltd (SPARC Pvt Ltd). The rats were housed in clean polypropylene cages, maintained in a temperature-controlled room $\left(25 \pm 2{ }^{\circ} \mathrm{C}\right)$ with a photoperiod of $12 \mathrm{~h}$ light and $12 \mathrm{~h}$ dark cycle. The rats were provided with a standard pellet diet (VRK Nutritional Solutions, Laboratory Animal Diets, Pune, India) and water ad libitum throughout the experimental period. The protocol for this study was approved by the Institutional Animal Ethics Committee (Regd. No. 1029/PO/ERe/S/07/CPCSEA) in its proposal number BIP/IAEC/ 2015/07 dated 3rd July 2015.

\section{Chemicals}

All chemicals used in the study were AnalaR grade and were obtained from the following scientific companies: Sigma (St. Louis, MO, USA); Fisher Scientific (Pittsburgh, PA, USA); Merck (Mumbai, India); Ranbaxy (New Delhi, India); Qualigens (Mumbai, India); SD Fine Chemical Limited (Gujarat, India); Chemdyes Corporation (Gujarat, India). Vitamin $\mathrm{E}$ and carvedilol were used as reference standards.

\section{Selection of the plant material}

Thespesia populnea (TP) belonging to Malvaceae family was selected for the present study owing to its acknowledged medicinal properties $[26,27]$. Fresh leaves of TP were collected. The plant material was taxonomically identified and authenticated (Voucher specimen No: BSI/AZRC/I.1202/Tech./2012-13 (P1. Id.)/719) by the Botanical Survey of India, Jodhpur, Rajasthan, India. The leaves were thoroughly cleaned, and the good ones were handpicked and shade-dried. Sufficient quantity of leaves was powdered in an electric grinder, sieved using a 24 mesh sieve to obtain fine leaf powder, which was used for extraction. The leaf powder was defatted with petroleum ether and then air-dried.

Following this, the powder was soaked in water and allowed for percolation [28] for $24 \mathrm{~h}$, and the solvent was filtered using a moist muslin cloth. The extract was recovered, water was added to the leaf powder and the extraction was continued. This process was repeated three to four times till a colourless extract was obtained. The extract was distilled and concentrated under reduced pressure in a Buchi Rotovapour (R-114) to yield a dark-colored residue and then dried in a vacuum desiccator to remove any remaining water $[29,30]$. The required quantity of aqueous extract was suspended in $5 \%$ gum acacia at required concentration doses, calculated according to the body weight, and used in all experiments [31].

\section{Dose fixation for TP leaf extract}

Dose-dependent studies were done to select the effective dose of TP leaf extract to counter ethanol effects. TP doses $(100,200,300,400$ and $500 \mathrm{mg} / \mathrm{kg}$ body wt.) were tested for their effectiveness by in vivo studies in rats for $28 \mathrm{~d}$, with 4 rats per dosage group, and ATPase activities were examined in the heart tissue. It was found that the effect was dose-dependent and doses from 200 to 400 $\mathrm{mg} / \mathrm{kg}$ of TP effectively up-regulated the enzyme activities. Hence, a lower dose of $200 \mathrm{mg} / \mathrm{kg}$ and a higher dose of $400 \mathrm{mg} / \mathrm{kg}$ were chosen for determining the efficacy of TP to counter ethanol effects.

\section{Treatment protocol}

The rats were divided into 10 groups of six animals each, and the treatment was given daily via orogastric tube for $6 \mathrm{w}$.
Group I: Received only $5 \%$ gum acacia ( $5 \mathrm{ml} / \mathrm{kg}$ per day p. o.) for $6 \mathrm{w}$ and served as vehicle control (VC).

Group II: Received only ethanol (20\%, 2g/kg, p. o.) for $6 \mathrm{w}$.

Group III: Received only aqueous leaf extract $(200 \mathrm{mg} / \mathrm{kg})$ for $6 \mathrm{w}$.

Group IV: Received only aqueous leaf extract ( $400 \mathrm{mg} / \mathrm{kg}$ ) for $6 \mathrm{w}$.

Group V: Received aqueous leaf extract $(200 \mathrm{mg} / \mathrm{kg}$ ) plus $20 \%$ ethanol, $2 \mathrm{~g} / \mathrm{kg}$, p. o. for $6 \mathrm{w}$.

Group VI: Received aqueous leaf extract $(400 \mathrm{mg} / \mathrm{kg}$ ) plus $20 \%$ ethanol, $2 \mathrm{~g} / \mathrm{kg}$, p. o. for $6 \mathrm{w}$.

Group VII: Received only vitamin E (25 mg/kg, p. o.) for 6 w. This group served as drug control or reference control.

Group VIII: Received vitamin E plus 20\% ethanol, 2g/kg, p. o. for $6 \mathrm{w}$.

Group IX: Received only carvedilol (1 mg/kg, p. o.) for $6 \mathrm{w}$. This served as drug control or reference control.

Group X: Received carvedilol plus 20\% ethanol, 2g/kg, p. o. for 6 w.

\section{Induction of ethanol-cardio toxicity and isolation of tissue}

Ethanol-cardiotoxicity was induced following Husain and Somani [32]. Ethanol $20 \%$ (2 g/kg, PO) was given via orogastric tube daily for $6 \mathrm{w}$ to the group. In the groups receiving TP extract $(200 \mathrm{mg} / \mathrm{kg}$ and $400 \mathrm{mg} / \mathrm{kg}$, respectively), vitamin E $(25 \mathrm{mg} / \mathrm{kg}$, p. o.) and carvedilol (1 $\mathrm{mg} / \mathrm{kg}$, p. o.) respectively, ethanol was given additionally via orogastric tube daily for $6 \mathrm{w}$. Individual control groups were maintained for all the groups under treatment. At the end of the dosing schedules for all the experimental groups, the heart was excised under euthanasia in chilled Tris buffer (10 mmol pH 7.4) and used to prepare homogenates for enzyme assays.

\section{Assay of ATPase activities}

ATPase activities were assayed by the method of Fritz and Hamrick [33] as reported by Desaiah and $\mathrm{Ho}$ [34]. $\mathrm{Na}^{+} / \mathrm{K}^{+}$and $\mathrm{Mg}^{2+} \mathrm{ATPase}$ activities were estimated in the mitochondrial fraction. The reaction mixture in a volume of $3.0 \mathrm{ml}$ contained 3 mmol ATP, $3 \mathrm{mmol}$ magnesium chloride $\left(\mathrm{MgCl}_{2}\right), 100 \mathrm{mmol}$ sodium chloride $\left(\mathrm{NaCl}_{2}\right), 20 \mathrm{mmol}$ potassium chloride $(\mathrm{KCl}), 135$ mmol imidazole-hydrochloric acid buffer (pH 7.5), and $0.3 \mathrm{ml}$ of mitochondrial suspension as the enzyme source. The reaction mixture was incubated at $37{ }^{\circ} \mathrm{C}$ for $30 \mathrm{~min}$. The reaction was stopped by the addition of $0.1 \mathrm{ml}$ of $50 \%$ trichloroacetic acid (TCA). The samples were then assayed for inorganic phosphate using the method of Lowry and Lopez [35] as modified by Phillips and Hayes [36].

The colour was read at $620 \mathrm{~nm}$ in a spectrophotometer. $\mathrm{Mg}^{2+}$ ATPase activity was measured in the presence of $1 \mathrm{mmol}$ ouabain, a specific inhibitor of $\mathrm{Na}^{+} / \mathrm{K}^{+}$ATPase [37]. Ouabain-sensitive $\mathrm{Na}^{+} / \mathrm{K}^{+}$ATPase activity was obtained from the difference between total ATPase activity and $\mathrm{Mg}^{2+} \mathrm{ATPase}$ activity. The enzyme activity was expressed as $\mu \mathrm{mol}$ of inorganic phosphate formed $/ \mathrm{mg}$ protein $/ \mathrm{h}$. $\mathrm{Ca}^{2+} \mathrm{ATPase}$ activity was determined by measuring the inorganic phosphate liberated during the hydrolysis of ATP. The activity was estimated in the mitochondrial fraction. The reaction mixture in a volume of 3.0 $\mathrm{ml}$ contained $135 \mathrm{mmol}$ imidazole-hydrochloric acid buffer ( $\mathrm{pH} 7.5)$, $5 \mathrm{mmol} \mathrm{MgCl}_{2}, 0.05 \mathrm{mmol} \mathrm{CaCl}_{2}, 4 \mathrm{mmol}$ ATP, and $0.3 \mathrm{ml}$ of mitochondrial suspension as the enzyme source. The reaction mixture was incubated at $37{ }^{\circ} \mathrm{C}$ for $30 \mathrm{~min}$ and stopped by the addition of $0.1 \mathrm{ml}$ of $50 \%$ TCA.

The inorganic phosphate formed was estimated by the method of Lowry and Lopez [35] as modified by Phillips and Hayes [36]. The colour was read at $620 \mathrm{~nm}$ in a spectrophotometer. $\mathrm{Mg}^{2+}$ ATPase activity was measured in the presence of $0.5 \mathrm{mmol}$ ethylene glycol tetra acetic acid (EGTA), and this value was subtracted from total ATPase activity to obtain $\mathrm{Ca}^{2+}$ ATPase activity. The enzyme activity was expressed as $\mu \mathrm{mol}$ of inorganic phosphate formed/mg protein/h. 


\section{Assay of antioxidant enzymes}

\section{Superoxide dismutase (SOD)}

SOD activity was determined according to the method of Misra and Fridovich [38] at room temperature. The heart tissue was homogenised in ice-cold $50 \mathrm{mmol}$ phosphate buffer $(\mathrm{pH} 7.0$ ) containing $0.1 \mathrm{mmol}$ ethylene diamine tetra acetic acid (EDTA) to give $5 \%$ homogenate $(\mathrm{w} / \mathrm{v})$. The homogenates were centrifuged at $10,000 \mathrm{rpm}$ for $10 \mathrm{~min}$ at $4{ }^{\circ} \mathrm{C}$. The supernatant was separated and used for enzyme assay. $100 \mu \mathrm{l}$ of tissue extract was added to $880 \mu \mathrm{l}$ carbonate buffer ( $0.05 \mathrm{M}, \mathrm{pH} 10.2$, containing $0.1 \mathrm{mmol}$ EDTA). $20 \mu \mathrm{l}$ of $30 \mathrm{mmol}$ epinephrine (in $0.05 \%$ acetic acid) was added to the mixture and the optical density was measured at $480 \mathrm{~nm}$ for $4 \mathrm{~min}$ in a Hitachi U-2000 Spectrophotometer. The enzyme activity was expressed as the amount of enzyme that inhibits the oxidation of epinephrine by $50 \%$, which is equal to 1 unit.

\section{Catalase (CAT)}

Catalase activity was measured by a slightly modified version of Aebi [39] at room temperature. The heart tissue was homogenised in ice cold $50 \mathrm{mmol}$ phosphate buffer (pH 7.0) containing $0.1 \mathrm{mmol}$ EDTA to give a $5 \%$ homogenate $(\mathrm{w} / \mathrm{v})$. The homogenates were centrifuged at $10,000 \mathrm{rpm}$ for $10 \mathrm{~min}$ at $4{ }^{\circ} \mathrm{C}$. The resulting supernatant was used as enzyme source. $10 \mu \mathrm{l}$ of $100 \% \mathrm{EtOH}$ was added to $100 \mu \mathrm{l}$ of tissue extract and then placed in an ice bath for $30 \mathrm{~min}$. Following this, the tubes were kept at room temperature and $10 \mu \mathrm{l}$ of Triton X-100 RS were added. In a cuvette containing $200 \mu \mathrm{l}$ of phosphate buffer and 50 $\mu \mathrm{l}$ of tissue extract, $250 \mu \mathrm{l}$ of $0.066 \mathrm{M} \mathrm{H}_{2} \mathrm{O}_{2}$ (in phosphate buffer) were added, and the decrease in optical density was measured at $240 \mathrm{~nm}$ for $60 \mathrm{~s}$ in a UV spectrophotometer. The molar extinction coefficient of $43.6 \mathrm{M} \mathrm{cm}^{-1}$ was used to determine CAT activity. One unit of activity is equal to the mol of $\mathrm{H}_{2} \mathrm{O}_{2}$ degraded/mg protein/min.

\section{Statistical analysis}

The assay of enzyme activities was carried out with six separate replicates from each group. The values were expressed as mean \pm standard deviation (SD) from six animals. The significance of differences between the control and treated animals for different parameters was determined by using one-way analysis of variance (ANOVA) followed by Tukey's multiple comparisons posthoc tests using Graphpad Prism 5 computer package software. P values of at least $<0.05$ were considered as statistically significant.

\section{RESULTS}

The levels of $\mathrm{Na}^{+} / \mathrm{K}^{+}$ATPase, $\mathrm{Ca}^{2+}$ ATPase, $\mathrm{Mg}^{2+}$ ATPase, SOD and CAT activities were recorded in the cardiac tissue in vehicle control and following the administration of ethanol, TP leaf extracts $(200 \mathrm{mg} / \mathrm{kg}$ and $400 \mathrm{mg} / \mathrm{kg}$ respectively), vitamin $\mathrm{E}(25 \mathrm{mg} / \mathrm{kg}$ ) and carvedilol $(1 \mathrm{mg} / \mathrm{kg})$ separately and after pre-treatment with TP leaf extracts, vitamin $\mathrm{E}$ and carvedilol before the administration of ethanol. The results are presented in Tables 1 and 2 and fig. 1 and 2. The changes in enzyme activities were expressed with reference to the vehicle control.

\section{$\mathrm{Na}^{+} / \mathrm{K}^{+}$ATPase}

The vehicle control group recorded the activity of $\mathrm{Na}^{+} / \mathrm{K}^{+} \mathrm{ATPase}$ at around $1.49 \mu \mathrm{mol}$. TP extract of $200 \mathrm{mg} / \mathrm{kg}$ did not cause any significant change in the control activity, whereas increases of $12.98 \%, 42.95 \%$ and $109.39 \%$ in the enzyme activity were recorded in groups that received TP leaf extract in the dose of $400 \mathrm{mg} / \mathrm{kg}$, vitamin $\mathrm{E}$ and carvedilol respectively. On the other hand, the rats that received ethanol showed a significant decrease of $46.98 \%$ in the enzyme activity. Pre-treatment with TP extract $(200 \mathrm{mg} / \mathrm{kg}$ or 400 $\mathrm{mg} / \mathrm{kg}$ ) or vitamin $\mathrm{E}$ or carvedilol before the administration of ethanol could revert this decrease by $102.53 \%, 140.52 \%, 120.25 \%$, and $146.83 \%$ respectively when compared to ethanol-administered group as the control, and brought back the activity to around the vehicle control (table 1; fig. 1).

\section{$\mathrm{Ca}^{2+}$ ATPase}

In vehicle control group, the $\mathrm{Ca}^{2+} \mathrm{ATPase}$ activity was found to be around 1.58 moles. TP leaf extract in the doses of $200 \mathrm{mg}, 400 \mathrm{mg}$, vitamin $\mathrm{E}$ and carvedilol caused significant increases in the enzyme activity by $7.59 \%, 34.18 \%, 18.99 \%$, and $1.9 \%$ respectively from the vehicle control. In contrast, administration of ethanol caused a significant decrease in the enzyme activity by $50 \%$. Pre-treatment with TP extract in both the doses, vitamin $\mathrm{E}$ and carvedilol before the administration of ethanol caused recovery of the enzyme activity from the level in ethanol-administered group by $107.59 \%, 130.38 \%$, $91.14 \%$, and $79.75 \%$ respectively, and reverted the activities to the vehicle control level (table 1; fig. 1).

\section{$\mathrm{Mg}^{2+}$ ATPase}

The vehicle control recorded the activity at around $3.52 \mu$ moles. The $\mathrm{Mg}^{2+}$ ATPase activity was lowered by $29.26 \%$ in ethanol-treated rats as compared to the vehicle control group. Administration of the TP leaf extract at 200 and $400 \mathrm{mg} / \mathrm{kg}$ respectively and vitamin $\mathrm{E}$ to the rats individually caused slight increases of $3.98 \%, 7.39 \%$, and $6.53 \%$ respectively in the enzyme activity, while a non-significant decrease of $8.24 \%$ was recorded with the administration of carvedilol. Pretreatment with TP extract at 200 or $400 \mathrm{mg}$, vitamin E or carvedilol prior to ethanol administration reverted the enzyme activity from the level in ethanol-treated group by $24.1 \%, 48.19 \%, 30.12$, and $26.51 \%$ respectively, and brought back the activity to the vehicle control level (table 1; fig. 1).

Table 1: Changes in $\mathrm{Na}^{+} / \mathrm{K}^{+} \mathrm{ATPase}, \mathrm{Mg}^{2+} \mathrm{ATPase}$ and $\mathrm{Ca}^{2+} \mathrm{ATPase}$ activities (expressed as $\mu \mathrm{mol}$ of inorganic phosphate formed/mg protein $/ \mathrm{h})$ in the presence of ethanol $(20 \%, 2 \mathrm{~g} / \mathrm{kg}, \mathrm{p.} \mathrm{o}$.), TP leaf extract $(200$ and $400 \mathrm{mg} / \mathrm{kg})$, vitamin $\mathrm{E}(25 \mathrm{mg} / \mathrm{kg}$, p. o.) and carvedilol $(1 \mathrm{mg} / \mathrm{kg}, \mathrm{p.} \mathrm{o}$.) separately and in combination

\begin{tabular}{lll}
\hline Experimental group & $\mathbf{N a}^{+} / \mathbf{K}^{+} \mathbf{A T P a s e}$ & $\mathbf{C a}^{2+} \mathbf{A T P a s e}$ \\
\hline Vehicle control (5\% Gum acacia) & $1.49 \pm 0.17$ & $1.58 \pm 0.15$ \\
Ethanol (20\%) & $0.79 \pm 0.12^{* * *}$ & $0.79 \pm 0.18^{* * *}$ \\
TP leaf extract (200 mg) & $1.50 \pm 0.18 \mathrm{NS}$ & $1.70 \pm 0.16 \mathrm{NS}$ \\
TP leaf extract (400 mg) & $1.67 \pm 0.19 \mathrm{NS}$ & $2.12 \pm 0.12^{* * *}$ \\
Standard (vitamin E) & $2.13 \pm 0.29^{* * *}$ & $1.89 \pm 0.14^{* *}$ \\
Carvedilol & $3.12 \pm 0.26^{* * *}$ & $1.61 \pm 0.10 \mathrm{NS}$ \\
TP leaf extract (200 mg)+ethanol & $1.60 \pm 0.12 \mathrm{NS}$ & $1.64 \pm 0.09 \mathrm{NS}$ \\
TP leaf extract (400 mg)+ethanol & $1.90 \pm 0.144^{* *}$ & $3.78 \pm 0.26 \mathrm{NS}$ \\
Vitamin E+ethanol & $1.74 \pm 0.20^{*}$ & $3.75 \pm 0.32 \mathrm{NS}$ \\
Carvedilol+ethanol & $1.95 \pm 0.22^{*}$ & $3.23 \pm 0.22 \mathrm{NS}$ \\
\hline
\end{tabular}

Note: Each value is mean \pm standard deviation (SD) of 6 independent observations. ${ }^{*} \mathrm{P}<0.05$; ${ }^{* *} \mathrm{P}<0.01$; ${ }^{* * *} \mathrm{P}<0.001$; NS: Not significant

\section{Superoxide dismutase (SOD)}

The vehicle control recorded the activity at around 16.45 units. SOD activity decreased by $54.16 \%$ in the ethanol-administered group compared to the vehicle control. Administration of the TP leaf extract at 200 or $400 \mathrm{mg} / \mathrm{kg}$, vitamin $\mathrm{E}$ and carvedilol to the rats individually caused increases of 5.11\%, 15.14\%, 9.91\%, and $13.01 \%$ respectively. Pre-treatment with TP extract at 200 or $400 \mathrm{mg}$, vitamin $\mathrm{E}$ or carvedilol prior to adding ethanol reverted the enzyme activity from the level in ethanol-treated group by 59.55\%, 82.76\%, $91.91 \%$, and $82.89 \%$ respectively, and brought back the activity to the level of vehicle control (table 2, fig. 2). 


\section{Catalase (CAT)}

In vehicle control, the CAT activity was found to be about $0.76 \mu$ moles. The activity decreased by $71.05 \%$ in the ethanol-treated group compared to the vehicle control. TP extract $(200$ or 400 $\mathrm{mg} / \mathrm{kg}$ ), vitamin $\mathrm{E}$, and carvedilol caused increases of $7.89 \%$, $14.47 \%, 3.95 \%$, and $6.58 \%$ respectively in the enzyme activity from the vehicle control. Pre-treatment with TP extract (200 or $400 \mathrm{mg} / \mathrm{kg}$ ) or vitamin $\mathrm{E}$ or carvedilol prior to ethanol administration reverted this decrease by $190.91 \%, 222.73 \%$, $231.82 \%$, and $204.54 \%$ respectively when compared to ethanol-administered group as the control, and brought back the activity to around the vehicle control (table 2, fig. 2).

Table 2: Changes in superoxide dismutase (SOD) (expressed as units of superoxide anion reduced $/ \mathrm{mg}$ protein/min) and catalase (CAT) (expressed as $\mu \mathrm{mol}$ of hydrogen peroxide $\left(\mathrm{H}_{2} \mathrm{O}_{2}\right)$ degraded $/ \mathrm{mg}$ protein $\left./ \mathrm{min}\right)$ activities in the presence of ethanol $(20 \%, 2 \mathrm{~g} / \mathrm{kg}, \mathrm{p.} \mathrm{o}$.), TP leaf extract (200 and $400 \mathrm{mg} / \mathrm{kg})$, vitamin $E(25 \mathrm{mg} / \mathrm{kg}$, p. o.) and carvedilol (1 mg/kg, p. o.) separately and in combination

\begin{tabular}{lll}
\hline Experimental group & SOD & Catalase \\
\hline Vehicle control (5\% Gum acacia) & $16.45 \pm 0.59$ & $0.76 \pm 0.07$ \\
Ethanol (20\%) & $7.54 \pm 0.45^{* * *}$ & $0.22 \pm 0.06^{* * *}$ \\
Thespesia leaf extract (200 mg) & $17.29 \pm 0.53 \mathrm{NS}$ & $0.82 \pm 0.03 \mathrm{NS}$ \\
Thespesia leaf extract (400 mg) & $18.94 \pm 0.55^{*}$ & $18.09 \pm 0.26 \mathrm{NS}$ \\
Standard (vitamin E) & $18.59 \pm 0.55^{*}$ & $0.87 \pm 0.05^{*}$ \\
Carvedilol & $12.03 \pm 0.48^{* * *}$ & $0.81 \pm 0.08 \mathrm{NS}$ \\
Thespesia leaf extract (200 mg)+ethanol & $13.78 \pm 0.56^{* * *}$ & $0.64 \pm 0.08^{*}$ \\
Thespesia Leaf extract (400 mg)+ethanol & $14.47 \pm 0.51^{*}$ \\
Vitamin E+ethanol & $13.79 \pm 0.55^{* * *}$ \\
Carvedilol+ethanol & & $0.71 \pm 0.14 \mathrm{NS}$ \\
\hline
\end{tabular}

Note: Each value is mean \pm standard deviation $(\mathrm{SD})$ of 6 independent observations. ${ }^{*} \mathrm{P}<0.05$; ${ }^{* * *} \mathrm{P}<0.001$; NS: Not significant
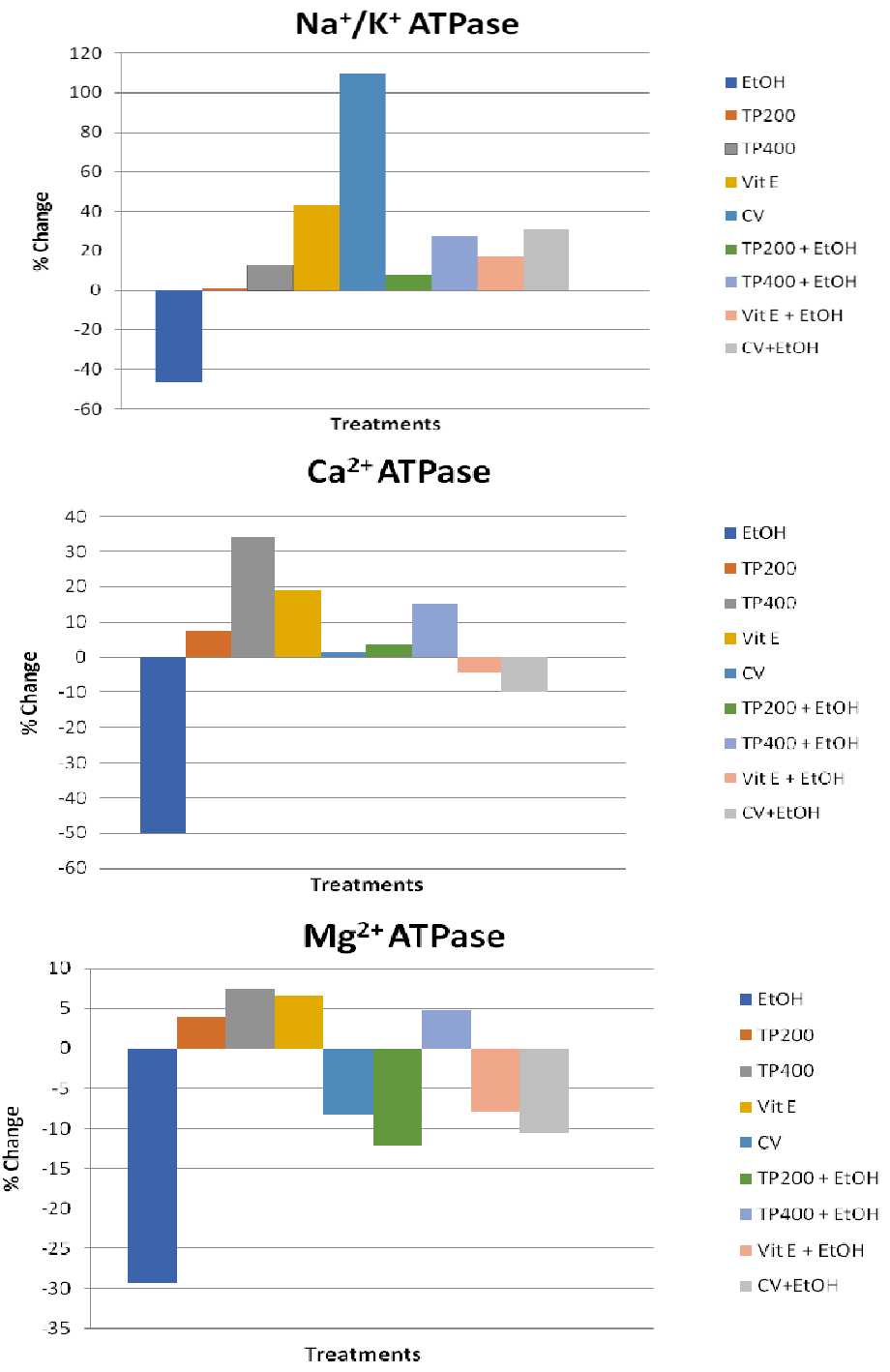

Fig. 1: Percent changes in $\mathrm{Na}^{+} / \mathrm{K}^{+}$ATPase, $\mathrm{Ca}^{2+}$ ATPase and $\mathrm{Mg}^{2+}$ ATPase enzyme activities in rat heart tissue following the administration of ethanol, TP leaf extract ( 200 and $400 \mathrm{mg} / \mathrm{kg}$ ), vitamin $E$ and carvedilol individually as well as in combination with ethanol. The percent changes between means each of 6 independent observations were calculated by comparing with vehicle controls. Note: EtOH-ethanol; TP 200 and TP 400-TP leaf extracts; Vit E-vitamin E; CV-carvedilol; TP 200+EtOH and TP 400+EtOH-TP leaf extracts+ethanol; Vit E+EtOHvitamin E+ethanol; CV+EtOH-carvedilol+ethanol 
Superoxide dismutase

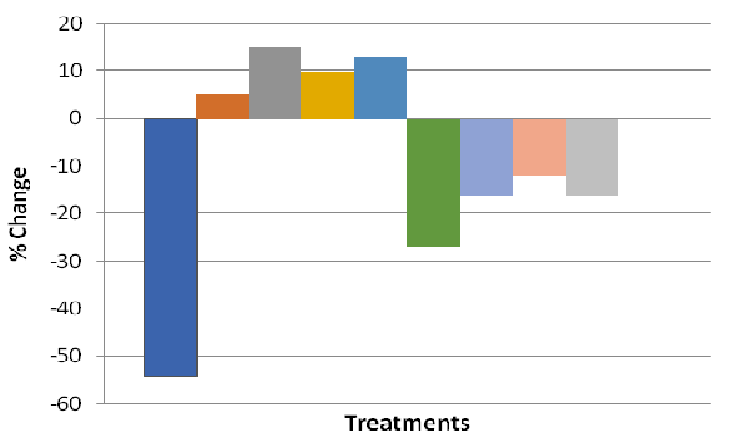

$\mathrm{EtOH}$

\section{- TP200}

- TP400

VitE

m CV

- TP200+EtOH

- TP4O0 $+\mathrm{EtOH}$

- Vit $\mathrm{E}+\mathrm{EtOH}$

$\mathrm{CV}+\mathrm{EtOH}$

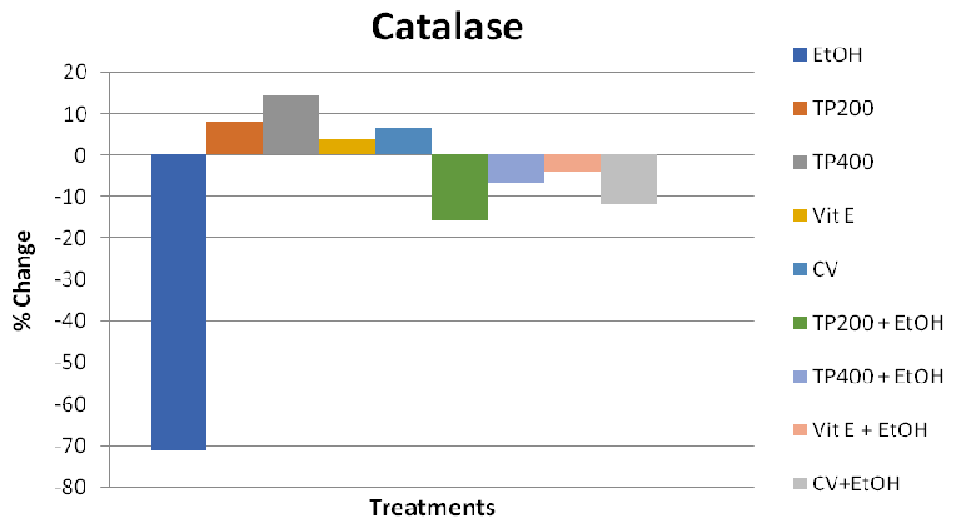

Fig. 2: Percent changes in superoxide dismutase and catalase enzyme activities in rat heart tissue following the administration of ethanol, TP leaf extract $(200$ and $400 \mathrm{mg} / \mathrm{kg}$ ), vitamin $E$ and carvedilol individually as well as in combination with ethanol. The percent changes between means each of 6 independent observations were calculated by comparing with vehicle controls. Note is same as for fig. 1

\section{DISCUSSION}

Acute and chronic administration of ethanol in several human and animal models has demonstrated cardiotoxic effect [40], with the major ethanol metabolite acetaldehyde contributing to cardiac dysfunction, hypertrophy and heart failure by either its direct toxicity or promoting elevated levels of catecholamines and ROS [41]. ATPases are membrane-bound enzymes involved in energymediated translocation of $\mathrm{Na}^{+}, \mathrm{Ca}^{2+}$ and $\mathrm{Mg}^{2+}$ ions [42]. Studies have shown a reduction in the activity of these enzymes upon damage to the myocardium $[43,44]$. Calcium overload in the myocardial cells during ischemia activates the $\mathrm{Ca}^{2+}$ ATPase, depleting high energy phosphate stores and thereby indirectly inhibiting $\mathrm{Na}^{+}$and $\mathrm{K}^{+}$ transport and inactivating $\mathrm{Na}^{+} / \mathrm{K}^{+}$ATPase [44]. Ethanol interacts with the cellular constituents causing profound changes in their structure, organisation and functions. Alteration in lipid components and ion-channels by ethanol can cause changes in membrane function by altering its fluidity [4] and thereby inhibition of $\mathrm{Na}^{+} / \mathrm{K}^{+} A T$ Pase and $\mathrm{Ca}^{2+}$ ATPase activities $[45,46]$.

As stated above, inhibition of ATPase activities in the present study is attributable to the interaction of ethanol with the cellular constituents [47]. Administration of TP extract at the dose of 200 $\mathrm{mg} / \mathrm{kg}$ had only a partial effect on elevating the ATPase activities when followed by ethanol administration, while significant improvement was observed with $400 \mathrm{mg} / \mathrm{kg}$ (table 1; fig. 1). Thus, TP extract in the dose of $400 \mathrm{mg} / \mathrm{kg}$ has greater efficacy in reverting the inhibitory effect of ethanol on ATPase enzymes. This observation points to a dose-dependent action of TP leaf extract on ethanol effect and is suggestive of TP leaf extract conferring a membrane stabilising protective effect.

TP leaf extract has been reported to exhibit hepatoprotective, antiinflammatory and antimicrobial effects $[26,27]$. This protection may be credited to the presence of antioxidant principles such as flavonoids, phenolic acids and saponins, which have proven antioxidant effects [48]. Thus, restoration of ATPase activity to normal by TP leaf extract in ethanol-treated rats is attributable to the presence of antioxidant phytoconstituents such as ferulic acid, synringic acid and vanillic acid etc. [19]. Therefore, restoration or elevation of the endogenous antioxidant enzyme activities to normal may be attributed to the antioxidant potential of TP protecting the ATPase enzymes from oxidative degradation.

Although several mechanisms have been suggested for the toxicity produced by ethanol, one of the most common mechanisms is by way of generation of free radicals [47]. The decrease in SOD activity due to ethanol indicates inefficient scavenging of ROS, which might be implicated to the oxidative inactivation of the enzyme [49]. Ethanol administration also reduces catalase activity in cardiac, liver, kidney and other tissues [50]. Results of the present study are in agreement with the earlier reports, with a reduction in the activity of SOD and CAT.

Vitamin $\mathrm{E}$ has been explored for its antioxidant benefits in various conditions of cardiotoxicity, and epidemiological data indicate an inverse association between cardiovascular risk and vitamin $\mathrm{E}$ intake from dietary sources and/or supplements $[43,51]$. The ameliorative effect of vitamin $\mathrm{E}$ in the present study could be attributed to its free radical scavenging ability. Earlier studies also credit the beneficial effect of vitamin $\mathrm{E}$ on membrane-bound enzymes to its potential to protect theSH groups from oxidative damage through the inhibition of peroxidation of membrane lipids [52].

Earlier reports from the literature suggest that the protective role of carvedilol on the heart is due to its antioxidant effect. Recent studies suggest that the drug protects against the oxidation of sarcoplasmic reticulum $\mathrm{Ca}^{2+}$ ATPase, inhibits oxidative damage to amino acids, and also reduces oxidative stress in the myocardium in patients with dilated cardiac myopathy $[53,54]$. Contrary to these reports on the ATPase elevating effects of carvedilol, the results of the present study showed a slight nonsignificant decrease in activity of $\mathrm{Mg}^{2+} \mathrm{ATPase}$ upon individual carvedilol treatment. Nevertheless, it was able to reduce the decrease caused by the treatment with alcohol when administered along with it. This effect of carvedilol on the membrane-bound enzymes is probably due to its inherent antioxidant activity as opposed to its beta-receptor blocking action. 
This is confirmed by studies indicating the anti-inflammatory and antioxidant properties of carvedilol [55].

The equilibrium between SOD and CAT activities is an important process for the effective removal of oxygen stress in intracellular organelles [56]. The heart tissue has less antioxidant enzyme activity compared to liver and other tissues, making it more vulnerable to peroxidative damage due to oxidative stress [32,57]. Therefore, the reduced capability of the heart tissue to eliminate superoxide and hydrogen peroxide radicals may thus predispose to oxidative stress in the tissue.

Under normal conditions, scavenging mechanisms operate swiftly to remove excess ROS. Experimental studies on TP have shown that the leaf extract exhibits free radical scavenging properties in vitro on hydroxyl radicals, peroxyl radicals, and superoxide free radicals [27]. In the present study SOD and CAT activities were restored to normal by TP leaf extract in rats co-administered with ethanol. These results are suggestive of the superoxide and hydrogen peroxide radical scavenging effects produced by the TP leaf extract in the cardiac tissue. This assumption is supported by the demonstrated in vitro radical scavenging potential of the plant [27]. Earlier studies on TP also report the antioxidant activity of the plant in different conditions $[17,58]$.

\section{CONCLUSION}

From the findings of the present study, it can be inferred that TP counters the changes in the activities of ATPases and antioxidant enzymes SOD and CAT brought about by ethanol administration, thereby reverting the abnormal changes towards normal. The use of TP in preventing the alterations in membrane homoeostasis and endogenous antioxidant enzymes could prove to be of benefit owing to the phytochemical protective constituents in the plant. Further studies with TP could provide a better understanding of the effects of the plant at the molecular level and the mechanisms involved in conferring cardioprotection.

\section{ACKNOWLEDGEMENT}

The authors are thankful to Gujarat Council on Science and Technology, Gujarat, India for extending partial financial support for this research through a Minor Research Project (Sanction Letter No. GUJCOST/MRP/2014-15/378 dated $30^{\text {th }}$ June 2014).

\section{AUTHORS' CONTRIBUTION}

This investigation was carried out by the first author Ms. Sangeetha L. A. Rajbanshi under the close supervision of Dr. Archana N. Paranjape ( $2^{\text {nd }}$ author) who directed the research and reviewed the manuscript and under the advice of the co-supervisor Dr. Vasu Appanna ( $3^{\text {rd }}$ author) who also reviewed the manuscript.

\section{CONFLICT OF INTERESTS}

The authors declare that there are no conflicts of interests.

\section{REFERENCES}

1. Ozaras R, Tahan V, Aydin S, Uzun H, Kaya S, Senturk H. Nacetylcysteine attenuates alcohol-induced oxidative stress in the rat. World J Gastroenterol 2003;9:125-8.

2. Inkielewicz I, Rogowska M, Krechniak J, Gdansk P. Lipid peroxidation and antioxidant enzyme activity in rats exposed to fluoride and ethanol. Fluoride 2006;39:53-9.

3. Nicholas ASH, Jun R. Short-term acetaldehyde exposure depresses ventricular myocyte contraction: the role of cytochrome P450 oxidase, xanthine oxidase, and lipid peroxidation. Alcohol Clin Exp Res 2003;27:577-83.

4. Rubin E, Rottenberg H. Ethanol-induced injury and adaptation in biological membranes. Fed Proc 1982;41:2465-71.

5. Kono Y, Fridovich I. Superoxide radical inhibits catalase. J Biol Chem 1982;57:5751-4.

6. Saravanan R, Prakasam A, Ramesh B, Pugalendi KV. Influence of Piper betle on hepatic marker enzymes and tissue antioxidant status in ethanol-treated Wistar rats. J Med Food 2004;5:197-204.

7. Luczaj W, Waszkiewicz E, Skrzydlewska E, RoszkowskaJakimiec W. Green tea protection against age-dependent ethanol-induced oxidative stress. J Toxicol Environ Health Part A 2004; 67:595-606.

8. Luczaj W, Stankiewicz-Kranc A, Milewska E, RoszkowskaJakimiec W, Skrzydlewska E. Effect of sweet grass extract against oxidative stress in rat liver and serum. Food Chem Toxicol 2012;50:135-40.

9. Durga M, Nathiya S, Devasena T. Protective role of fenugreek leaf extract and quercetin against petrol exhaust nanoparticle induced lipid peroxidation and oxidative stress in rat erythrocytes in vitro. Asian J Pharm Clin Res 2015;8:237-41.

10. Akilandeswari V, Sekkizhar M, Sylvia Santhakumari A, Nirmala P. Nephroprotective effect of lycopene in hyperglycemia induced oxidative stress in male Wistar rats. Int J Curr Pharm Res 2015;7:77-9.

11. Deepa Philip C, Indira Kumari R, Lavanya B. Phytochemical analysis, the antioxidant and antimicrobial activity of white and pink Psidium guajava Linnaeus. Int J Curr Pharm Res 2015;7:29-31.

12. Warrier PK, Nambiar VPK, Ramankutty C. Indian medicinal plants-4. Vol. 5. Chennai: Orient Longman Ltd; 1994.

13. Milbrodt M, Konig WA, Hausen BM. 7-hydroxy-2,3,5,6tetrahydro-3,6,9-trimethylnaphtho[1,8-b,c] pyran-4,8-dione from Thespesia populnea. Phytochemistry 1997;45:1523-5.

14. Sathyanarayana T, Sarita T, Balaji M, Ramesh A, Boini MK. Antihyperglycemic and hypoglycemic effect of Thespesia populnea fruits in normal and alloxan-induced diabetes in rabbits. Saudi Pharm J 2004;12:107-11.

15. Haja Sherief S, Moideen K, Sengottuvelu S, Sivakumar T. Antidiabetic effect of methanolic extract of Thespesia populnea flower and leaf in normal and alloxan-induced diabetic rats. Int J Res Ayurveda Pharm 2011;2:936-9.

16. Shirwaikar A, Kumar AV, Krishnanand BR, Sreenivasan KK. Chemical investigation and antihepatotoxic activity of Thespesia populnea. Int J Pharmacogn 1995;33:305-10.

17. Ilavarasan R, Vasudevan M, Anbazhagan S, Venkataraman S, Sridhar SK. Hepatoprotective activity of Thespesia populnea bark extracts against carbon tetrachloride-induced liver toxicity in rats. Nat Prod Sci 2003a;9:83-6.

18. Ilavarasan R, Vasudevan M, Anbazhagan S, Venkataraman S. Antioxidant activity of Thespesia populnea bark extracts against carbon tetrachloride-induced liver injury in rats. J Ethnopharmacol 2003b;87:227-30.

19. Rastogi RP, Mehrotra BN. Compendium of Indian Medicinal Plants. Vol. 5. Lucknow, CDRI, New Delhi: Publication and Information Directorate; 1979.

20. Tokyoshima C. How $\mathrm{Ca}^{2+}$ ATPase pumps ions across the sarcoplasmic reticulum membrane. Biochim Biophys Acta 2009;1793:941-6.

21. Pushpakiran G, Mahalakshmi K, Viswanathan P, Anuradha CV. Taurine prevents ethanol-induced alterations in lipids and ATPases in rat tissues. Pharmacol Rep 2005;57:578-87.

22. Gonzalez-Calvin JL, Saunders JB, Williams R. Effects of ethanol and acetaldehyde on hepatic plasma membrane ATPases. Biochem Pharmacol 1983;32:1723-8.

23. Pallavi S, Ambuj Bhushan J, Rama Shanker D, Mohammad P. Reactive oxygen species, oxidative damage, and antioxidative defence mechanism in plants under stressful conditions. J Bot 2012:1-26. Doi:10.1155/2012/217037

24. Ichikawa I, Kiyama S, Yoshioka T. Renal antioxidant enzymes: their regulation and function. Kidney Int 1994;45:1-9.

25. Sharma M, Kishore K, Gupta SK, Joshi S, Arya D. Cardioprotective potential of Ocimum sanctum in isoproterenol induced myocardial infarction in rats. Mol Cell Biochem 2001;225:75-83.

26. Elakkiya S, Ananthi T. Studies on anti-inflammatory activity of Thespesia populnea Linn. on the drug induced male albino rats. J Chem Pharm Res 2011;3:473-7.

27. Sahitya Chetan P, Shanmugam RK, Sangeetha LR, Pavan NK, Saritha $\mathrm{P}$, Murali Mohan $\mathrm{P}$, et al. Alterations in antioxidant enzyme activities and oxidative damage in alcoholic rat tissues: protective role of Thespesia populnea. Food Chem 2012;132:150-9.

28. Agrawal SS, Paridhavi M. Herbal drug technology. Hyderabad: Universities Press (India) Private Limited; 2007. 
29. Makkar HP, Bluemmel M, Borowy NK, Becker K. Gravimetric determination of tannins and their correlations with chemical and protein precipitation methods. J Sci Food Agric 1993;61:161-5.

30. Zhishen J, Mengcheng T, Jianming W. The determination of flavonoids contents in mulberry and their scavenging effects on superoxide radicals. Food Chem 1999;64:555-9.

31. Ghosh MN. Fundamentals of experimental pharmacology. 2nd ed. Calcutta: Scientific Book Agency Publisher; 1984.

32. Husain $\mathrm{K}$, Somani SM. The response of cardiac antioxidant system to alcohol and exercise training in the rat. Alcohol 1997; 14:301-7.

33. Fritz PJ, Hamrick ME. Enzymatic analysis of adenosine triphosphatase. Enzymologia 1966;30:57-64.

34. Desaiah D, Ho IK. Effect of acute and continuous morphine administration on catecholamine-sensitive adenosine triphosphatase in mouse brain. J Pharmacol Exp Ther 1979; 208:80-5.

35. Lowry $\mathrm{OH}$, Lopez JA. The determination of inorganic phosphate in the presence of labile phosphate esters. J Biol Chem 1946;162:421-8.

36. Phillips TD, Hayes AW. Effects of patulin on ATPase in the mouse. Toxicol Appl Pharmacol 1977;42:175-88.

37. McIlwain H. Chemical exploration of the brain: a study of ion movement and cerebral excitability. Amsterdam: Elsevier Publishing Co; 1963.

38. Misra HP, Fridovich I. The role of superoxide anion in the autooxidation of epinephrine and a simple assay of SOD. J Biol Chem 1972;247:3170-5.

39. Aebi H. Oxido reductases acting on groups other than $\mathrm{CHOH}$ : Catalase. In: Colowick SP, Kaplan NO, Packer L. editors. Methods in Enzymology. London: Academic Press; 1984. p. 121-5.

40. Beckemeier ME, Bora PS. Fatty acid ethyl esters: potentially toxic products of myocardial ethanol metabolism. J Mol Cell Cardiol 1998;30:2487-94.

41. Zhang Y, Ren J. Autophagy in ALDH2-elicited cardioprotection against ischemic heart disease: slayer or saviour? Autophagy 2010;6:1212-3.

42. Rappas M, Niwa H, Zhang X. Mechanisms of ATPases--a multidisciplinary approach. Curr Protein Pept Sci 2004;5:89-105.

43. Upaganlawar A, Gandhi H, Balaraman R. Effect of green tea and vitamin $\mathrm{E}$ combination on isoproterenol induced myocardial infarction in rats. Plant Foods Hum Nutr 2009;64:75-80.

44. Upaganlawar A, Balaraman R. Cardioprotective effects of Lagenaria siceraria fruit juice on isoproterenol-induced myocardial infarction in Wistar rats: A biochemical and histoarchitecture study. J Young Pharm 2011;3:297-303.

45. Bing RJ. Effect of alcohol on the heart and cardiac metabolism. Fed Proc 1982;41:2443-6.

46. Rosario Sepúlveda M, Mata AM. The interaction of ethanol with reconstituted synaptosomal plasma membrane Ca2+- ATPase. Biochim Biophys Acta-Biomembr 2004;1665:75-80.
47. Bondy SC. Ethanol toxicity and oxidative stress. Toxicol Lett 1992;63:227-9.

48. Prince PSM, Dhanasekar K, Rajakumar S. Vanillic acid prevents altered ion pumps, ions, inhibits Fas-receptor and caspase mediated apoptosis-signaling pathway and cardiomyocyte death in myocardial infarcted rats. Chem Biol Interact 2015;232:68-76.

49. Pigeolet E, Corbisier P, Houbion A, Lambert D, Michiels C, Raes $\mathrm{M}$, et al. Glutathione peroxidase, superoxide dismutase, and catalase inactivation by peroxides and oxygen derived free radicals. Mech Ageing Dev 1990;51:283-97.

50. Shanmugam KR, Mallikarjuna K, Kesireddy N, Chen CY, Kuo CH, Sathyavelu RK. Ginger feeding protects against renal oxidative damage caused by alcohol consumption in rats. J Renal Nutr 2011;21:263-70.

51. Jha P, Flather M, Lonn E, Farkouh M, Yusuf S. The antioxidant vitamins and cardiovascular disease: a critical review of epidemiologic and clinical trial data. Ann Intern Med 1995;123:860-72.

52. Upaganlawar A, Gandhi H, Balaraman R. Effect of vitamin E alone and in combination with lycopene on biochemical and histopathological alterations in isoproterenol-induced myocardial infarction in rats. J Pharmacol Pharmacother 2010;1:24-31.

53. Dandona P, Karne R, Ghanim H, Hamouda W, Aljada A, Magsino $\mathrm{CH}$. Carvedilol inhibits reactive oxygen species generation by leukocytes and oxidative damage to amino acids. Circulation 2000;101:122-4

54. Nakamura K, Kusano K, Nakamura Y. Carvedilol decreases elevated oxidative stress in human failing myocardium. Circulation 2002;105:2867-71.

55. Yuan Z, Shioji K, Kihara Y, Takenaka H, Onozawa Y, Kishimoto C. Cardioprotective effects of carvedilol on acute autoimmune myocarditis: anti-inflammatory effects associated with the antioxidant property. Am J Physiol Heart C 2004;286:83-90.

56. Sharma M, Kishore K, Gupta SK, Joshi S, Arya D. Cardioprotective potential of Ocimum sanctum in isoproterenol induced myocardial infarction in rats. Mol Cell Biochem 2001;225:75-83.

57. Kalyanaraman B, Joseph J, Kalivendi S, Wang S, Konorev E, Kotamraju S. Doxorubicin-induced apoptosis: implications in cardiotoxicity. Mol Cell Biochem 2002;234-5:119-24.

58. Solomon S, Muruganantham N, Senthamilselvi MM. The antioxidant and anti-inflammatory activity of Thespesia populnea (Flowers). Pharmacophore 2015;6:53-9.

\section{How to cite this article}

- Sangeetha LA Rajbanshi, Archana N Paranjape, Vasu Appanna. Ethanol-induced alterations in cardiac enzymes-ameliorative effect of Thespesia populnea leaf extract. Int J Pharm Pharm Sci 2017;9(8):161-167. 